\title{
JAK PRZYGOTOWYWANI SAZ UŻYTKOWNICY DO WIZYTY W ARCHIWUM? ANALIZA PORÓWNAWCZA STRON INTERNETOWYCH WYBRANYCH ARCHIWÓW NA ŚWIECIE
}

\section{Słowa kluczowe}

benchmarking, użytkownicy archiwów, szkolenie użytkowników archiwów, kształcenie użytkowników archiwów

\section{Keywords}

benchmarking, archive users, training of archive users, education of archive users

\section{Streszczenie}

Artykuł jest raportem z badania wybranych stron internetowych narodowych archiwów zagranicznych pod kątem przygotowywania użytkowników do wizyty osobistej. Jest to

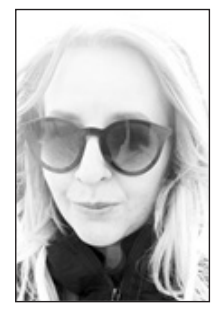

Monika Cołbecka, doktor nauk humanistycznych w dyscyplinie historia na podstawie pracy pt. „Usługi informacyjne archiwów” obronionej w roku 2020 w Uniwersytecie Mikołaja Kopernika w Toruniu. Od 2019 r. pracuje na stanowisku asystenta w Instytucie Historii i Archiwistyki Uniwersytetu Pedagogicznego im. KEN w Krakowie. Jej zainteresowania badawcze obejmują: teorię archiwistyki, informacyjny wymiar tej dyscypliny naukowej, użytkowników archiwów - bariery, potrzeby i ich zachowania informacyjne.

E-mail: monika.colbecka@wp.pl

ORCID ID: 0000-0002-6494-2115 
kontynuacja prowadzonych przez autorkę badań nad sposobami kształcenia użytkowników archiwów w środowisku wirtualnym. Sieć WWW jest obecnie ważnym kanałem informowania o instytucji, a także nawiązywania relacji z otoczeniem. Internet stał się istotnym narzędziem w budowaniu wizerunku archiwum. Dlatego ważnym jest podejmowanie badań witryn WWW. Umiejętność wskazania słabych i mocnych ich punktów może przynieść wymierną korzyść jaką jest podniesienie efektywności informacyjnej stron internetowych. Badanie polegało na wytypowaniu elementów, które powinny zostać porównane. W tym przypadku były to treści zawarte na stronach internetowych, które służą pośrednio lub bezpośrednio przygotowaniu użytkownika do wizyty osobistej. Dalej nastąpił dobór próby, czyli serwisów WWW narodowych archiwów zagranicznych, które spełniły określone kryteria. Następnie zrealizowano badanie metodą benchmarkingu oraz przedstawiono najlepsze praktyki oraz wnioski zmierzające do doskonalenia stron internetowych pod kątem wirtualnego kształcenia użytkowników archiwów.

\section{Summary}

How are users prepared to visit the archive? Comparative analysis of websites of selected archives in the world

The article is a report on the study of selected websites of national archives abroad in terms of preparing users for a personal visit. It is a continuation of the author's research on the methods of educating users of archives in the virtual environment. The World Wide Web is now an important channel of informing about the institution, as well as establishing relations with the environment. The Internet has become an important tool in building the image of the archive. Therefore, it is vital to undertake web site research. The ability to identify their strengths and weaknesses can bring a measurable benefit, which is increasing the information efficiency of websites. The research consisted in selecting the elements that should be compared. In this case, it was the content of websites that serves directly or indirectly to prepare the user for a personal visit. Next, a sample was selected, i.e. websites of national archives from abroad that met certain criteria. Then, a benchmarking study was carried out and the best practices and conclusions aimed at improving websites in terms of virtual education of archive users were presented.

\section{Ważność i aktualność problematyki}

( ieć WWW przez ostatnie dwadzieścia lat stała się ważnym filarem działań J) podejmowanych przez archiwa. W latach siedemdziesiątych i osiemdziesiątych dwudziestego wieku, kiedy archiwiści polscy dostrzegli i zaczęli się zajmować kwestią związków archiwistyki z bibliotekoznawstwem i informacją 
naukową ${ }^{1}$ (obecnie bibliologii i informatologii ${ }^{2}$ ), nikt, nawet $\mathrm{w}$ rozważaniach futurologicznych nie przewidywał jak ważne miejsce w komunikacji między użytkownikiem a instytucją archiwalną zajmie Internet. Obecnie już wszystkie archiwa państwowe w Polsce posiadają swoje strony internetowe. Nie są już postrzegane jedynie jako wizytówka ${ }^{3}$, ponieważ mnogość informacji na nich zawartych odbiega od definicji tego pojęcia ${ }^{4}$. Jednak nie tylko witryna WWW danego archiwum świadczy i informuje o nim. Hartmut Weber dwie dekady temu zwrócił uwagę na to, że Internet tworzy sieć powiązanych między sobą informacji - o archiwum, o zasobie oraz poprzez możliwość uzyskania bezpośredniego dostępu do materiałów archiwalnych ${ }^{5}$. Nie odbywa się to w obrębie jednego serwisu, a poprzez sieć powiązanych stron internetowych, katalogów i baz danych, które wspólnie mogą oferować kompleksową informację.

${ }^{1}$ M. in. H. Barczak, Wybrane zagadnienia informacji archiwalnej, Warszawa 1975; H. Barczak, S. Nawrocki, C. Włodarska, Zagadnienia informacji naukowej $w$ archiwach państwowych, „Archeion” 1971, t. 56, s. 33-49; M. Gołembiowski, Potrzeby informacyjne u̇̇ytkowników informacji archiwalnej, "Zagadnienia informacji naukowej” 1979, nr 1, s. 85-110; M. Gołembiowski, System informacji archiwalnej, Warszawa-Łódź 1985; A. Igielski, Potrzeby informacyjne indywidualnych użytkowników dokumentacji archiwalnej. Zakres i metody badań, „Archiwista” 1979, nr 1-2, s. 25-34; B. Kroll, Charakter i perspektywy tradycyjnego i archiwalnego systemu wyszukiwania informacji, „Archeion” 1977, t. 65, s. 61-84; S. Nawrocki, Archiwum jako ośrodek informacji, „Informatyka i archiwa” 1981, nr 11, s. 3-18; S. Nawrocki, Komputer $w$ stużbie archiwalnej, Poznań 1985; S. Nawrocki, Kształcenie użytkowników informacji $w$ archiwach, „Archeion” 1981, t. 72, s. 7-15; B. Ryszewski, Problemy i metody badawcze archiwistyki, Toruń 1985.

${ }^{2}$ Bibliologia i informatologia, zgodnie z Rozporządzeniem Ministra Nauki i Szkolnictwa Wyższego od 1 października 2018 r., nie jest już odrębną dyscypliną naukową (podobnie jak archiwistyka), a wchodzi w zakres nauki o komunikacji społecznej i mediach; Rozporządzenie Ministra Nauki i Szkolnictwa Wyższego z dnia 20 września 2018 r. $w$ sprawie dziedzin nauki i dyscyplin naukowych oraz dyscyplin artystycznych, „Dziennik Ustaw", 2018, poz. 1818; Zależności między nowa klasyfikacją dziedzin i dyscyplin a wcześniej obowiązującym wykazem i systematyka OECD, https://konstytucjadlanauki.gov. pl/content/uploads/2018/09/nowy-podzia-dyscyplin-tabela.pdf (dostęp 11.09.2020).

${ }^{3}$ R. Degen, Witryna internetowa archiwum - wizytówka czy element systemu informacji naukowej, [w:] Historyk - Archiwista - Komputer. Historyk a nowoczesny system informacji archiwalnej. Materiały konferencji Toruń, 10-11 kwietnia 2003, red. R. Degen i H. Robótka, Toruń 2004, s. 129-139.

4 Jedno ze znaczeń w słowniku języka polskiego to „coś, co świadczy o cechach kogoś lub czegoś, zwłaszcza dodatnich”; Wizytówka, [w:] Słownik języka polskiego PWN, https://sjp.pwn.pl/sjp/wizytowka;2579957.html (dostęp 20.06.2020).

${ }^{5} \mathrm{H}$. Weber, Skorzystaj z klucza i zagraj w grę - archiwa $w$ społeczeństwie informacyjnym i ksztatcacym się, „Archeion” 2004, t. 107, s. 22. 
Nie jest jednak łatwo określić miejsca jakie strona internetowa zajmuje w działalności archiwów. Służy ona użytkownikom i archiwistom, informuje o samej instytucji i jej zasobie, ale pozwala również załatwiać poprzez ten kanał coraz więcej spraw (m.in. składać rewersy). Jesteśmy już w stanie mówić o etapach rozwoju sieci od Web 1.0, poprzez Web 2.0 do Web 3.0 (tzw. sieci semantycznej), czyli „od modelu informacyjnych, ale statycznych stron internetowych przeszliśmy do modelu dynamicznych zasobów oraz interaktywnego udziału użytkowników w ich tworzeniu"6. Sieć semantyczna staje się bardziej zautomatyzowaną i rozumną ścieżką dostarczania informacji ${ }^{7}$. Strony internetowe stanowią ogromną wartość wizerunkową, przy czym są też w coraz większym stopniu narzędziem wypełniania misji powierzonej archiwom. Naturalnym wydaje się zatem podejmowanie badań witryn WWW w celu wskazywania słabych punktów i ich doskonalenia ${ }^{8}$. Celem artykułu jest poznanie możliwych do wykorzystania metod badawczych i ich zastosowanie w dziedzinie archiwalnej.

Obecnie nie jest już możliwe analizowanie stron internetowych archiwów w sposób ogólny. Witryny są rozbudowane i spełniają tak wiele zadań, że prowadzenie badań, które nie są skupione na konkretnej problematyce byłoby zbyt czasochłonne, bądź przynosiło wnioski zbyt ogólne.

Nie będzie przesadnym przypuszczenie, że strony internetowe archiwów stały się dla wielu użytkowników pierwszym punktem zetknięcia z tą instytucją. Czy dla dużej części społeczeństwa Internet jest podstawowym źródłem wiedzy o otoczeniu? Czy właśnie w środowisku WWW szukamy podstawowych informacji, gdy mamy w planach udanie się do jakiejkolwiek placówki? W większej liczbie przypadków odpowiedź będzie twierdząca. Jednak nie można zapominać o grupie osób, dla której postępująca cyfryzacja życia jest równoznaczna $\mathrm{z}$ alienacją i zagubieniem. Zrozumiałym staje się, że archiwa powinny być otwarte na ogół społeczeństwa, również tego wykluczonego informacyjnie i technologicznie?.

${ }^{6}$ G. Gmiterek, Od Web 1.0 do Web 3.0. Interaktywność a ewolucja sieci, [w:] Nauka o informacji, red. W. Babik, Warszawa 2016, s. 612.

7 Tamże, s. 613.

${ }^{8}$ M. Kowalska, Analiza porównawcza jakości serwisów WWW bibliotek wyższych szkót niepaństwowych województwa kujawsko-pomorskiego, „Folia Toruniensia” 2008, t. 8, s. 117.

9 O powodach braku dostępu do Internetu zob.: Społeczeństwo informacyjne w Polsce w 2019 r., https://stat.gov.pl/obszary-tematyczne/nauka-i-technika-spoleczenstwo -informacyjne/spoleczenstwo-informacyjne/spoleczenstwo-informacyjne-w-polsce-w2019-roku,2,9.html (dostęp 21.06.2020). 
Łatwo jest zauważyć przeglądając strony internetowe instytucji informacyjnych, że coraz więcej działań przez nie podejmowanych ma odzwierciedlenie w środowisku WWW. Dużym wyzwaniem staje się sprostanie nieustannym dążeniem do wiedzy i podnoszeniem kwalifikacji przez społeczeństwo uczące się, którego wymagania wzrastają. Środowisko internetowe jest obecnie najszybszym środkiem dla pozyskania informacji o funkcjonowaniu i ofercie. Wymaga podkreślenia, że otrzymane w ten sposób informacje pochodzą od źródła - to twórca decyduje jakie treści trafią do użytkownika.

Jeśli strona internetowa archiwum stanowi źródło wiedzy o tej instytucji, jej zasobie i procedurach w niej się odbywających, staje się ona też miejscem, które przygotowuje użytkownika do wizyty osobistej, kształci go. Jest to usługa szczególna, ponieważ ma wpływ na efektywność przeprowadzonych poszukiwań i ocenę, jaka zostanie wystawiona instytucji. Waldemar Chorążyczewski zauważył, że ważne jest, żeby społeczeństwo było odpowiednio wyedukowane w zakresie docierania i wykorzystywania informacji ${ }^{10}$.

Zagadnienie kształcenia użytkowników do korzystania z materiałów archiwalnych pojawia się w literaturze archiwistycznej już od dwudziestolecia międzywojennego ${ }^{11}$. Archiwiści-praktycy sygnalizowali problem nieprzygotowania do pracy z materiałami archiwalnymi osób przychodzących do pracowni naukowych. Wskazywali, że początkujący badacze potrzebują pomocy archiwistów, co zwiększa ich obowiązki i nakład pracy ${ }^{12}$. Te trudności pojawiają się do dziś, jednak zmieniły miejsce swojego „występowania” - część treści, stanowiących odpowiedzi na pytania archiwa publikują na swoich stronach internetowych.

Przed pojawieniem się i upowszechnieniem Internetu użytkownik był przygotowywany do prowadzenia kwerendy archiwalnej, pracy z archiwaliami, a także poznawał funkcjonowanie tej instytucji w kontakcie bezpośrednim z pracownikiem archiwum (ewentualnie telefonicznie czy korespondencyjnie). Obecnie wachlarz możliwości uległ poszerzeniu. Kształcenie może odbywać się

${ }^{10}$ W. Chorążyczewski, Archiwista przyszłości - edukator i autopromotor $w$ społeczeństwie informacyjnym, [w:] Archiwa w nowoczesnym społeczeństwie. Pamiętnik V Zjazdu Archiwistów Polskich. Olsztyn, 6-8 września 2007, red. J. Poraziński i K. Stryjkowski, Warszawa 2008, s. 48.

11 W. Hejnosz, Jeszcze o archiwach, bibliotekach i ich publicznej użyteczności naukowej, „Archeion” 1938-1939, t. 16, s. 86.

${ }^{12}$ M. Bielińska, Stan i zadania archiwów wobec aktualnych potrzeb nauki historycznej, „Archeion” 1956, t. 26, s. 14; S. Wójcikowa, J. Rogala, Udostępnianie zbiorów w pracowni Archiwum Państwowego m.st. Warszawy w latach 1967-1977, „Archeion” 1979, t. 69, s. 207-220. 
w sposób bezpośredni, wirtualny, dla grup lub indywidualnych użytkowników. Osoba, która pojawi się w archiwum może przyjść już z pewną wiedzą, wynikającą z tego co odnajdzie na stronie internetowej danej instytucji, dlatego istotne wydaje się odpowiednie przygotowanie tej treści. W dobie, gdy archiwa dysponują już takimi informacjami na stronach WWW, zasadnym wydaje się poznanie tych witryn (również zagranicznych), porównanie oraz dostrzeżenie najlepszych praktyk na tym polu. Podkreślenia wymaga, że ocenie nie będą podlegać treści merytoryczne związane z metodyką lokalną. Nie jest moją intencją ich ocena, a jedynie poznanie możliwych sposobów kształcenia i interakcji z użytkownikami poprzez witryny internetowe archiwów zagranicznych.

\section{Stan badań}

Badania porównawcze witryn internetowych instytucji informacyjnych (archiwów, bibliotek) są już prowadzone i dotyczą różnorodnych problemów. Strony WWW archiwów państwowych wraz ze studentami analizował Dariusz Magier. Raport z tego badania został opublikowany w roku 2004. Przedmiotem eksperymentu była strefa informacyjna i szata graficzna witryn WWW. Stworzono najpierw model idealnej strony w oczach potencjalnego odbiorcy treści i porównano go ze stanem faktycznym. Jak podkreślono we wnioskach z badania, celem nie było wytykanie błędów, a wskazanie najlepszych praktyk ${ }^{13}$.

Kolejnym przykładem badania jest przeprowadzona przeze mnie analiza porównawcza stron internetowych wszystkich archiwów państwowych i Naczelnej Dyrekcji Archiwów Państwowych pod kątem ich oferty w zakresie kształcenia użytkowników ${ }^{14}$. Pierwsze badanie przeprowadziłam w roku 2018. Dla zaobserwowania dynamiki zmian, które następują w środowisku wirtualnym dokonałam jego powtórzenia w 2020 r. ${ }^{15}$ Problemem jaki mnie zainteresował była konfrontacja archiwistów z użytkownikami w przestrzeni wirtualnej. Badania pozwoliły mi dokonać pełnej analizy, w związku z czym możliwe stało się przedstawienie propozycji zmian. Jednym z wniosków było to, że archiwa

13 D. Magier, Archiwa, studenci i Internet, czyli archiwistyka i archiwa widziane przez monitor PC. Raport z badań, „Archiwista Polski” 2014, nr 4 (76), s. 71-79.

${ }^{14}$ M. Cołbecka, Oferta archiwów $w$ Internecie $w$ zakresie kształcenia użytkowników, [w:] Popularyzacja nauk historycznych - teoria i praktyka. Zbiór studiów, red. D. Gołaszewska-Rusinowska, M. Mielewska, T. Sińczak, Toruń 2018, s. 65-80.

15 Raport z badania zawarty w dysertacji doktorskiej: M. Cołbecka, Ustugi informacyjne archiwów. Toruń 2020, Dział Zbiorów Specjalnych BUMK. 
nie czerpią nawzajem ze swoich doświadczeń, dlatego wydaje się zasadne stworzenie ogólnego podręcznika dobrych praktyk, czyli zestawu narzędzi do rozwiewania najczęstszych wątpliwości użytkowników. Jednak krok ten powinien być poprzedzony pogłębionym badaniem wykraczającym poza sieć stron internetowych polskich archiwów państwowych. W kolejnym etapie moich badań (wynikającym z wniosków polskich) postanowiłam przyjrzeć się praktykom wybranych archiwów narodowych na świecie.

Temat pośredniego przygotowywania użytkowników do wizyty w archiwach jest poruszany za granicą. Bardzo ciekawie przedstawia się inicjatywa podjęta przez Scotta P. Pitol'a, naukowca z Uniwersytetu Illinois w Chicago. Stworzył on ARPO Index - narzędzie (dostępne od roku 2017) do oceny komponentów stron internetowych, które przygotowują badacza do wizyty na miejscu w czytelni ${ }^{16}$. Naukowiec ten w artykule, który dotyczył stworzonego przez siebie indeksu dokonał przeglądu literatury, dotyczącej badań użytkowników archiwalnych stron internetowych, w tym historyków i genealogów, użyteczności wirtualnych pomocy archiwalnych oraz metod analizy zawartości witryn $W W W^{17}$. Z dokonanego przez niego przeglądu wynika, że szczególne zainteresowanie tym tematem przypadło na okres przełomu XX i XXI wieku. Scott P. Pitol stwierdził, że można było odczuć w tamtym okresie potrzebę intensyfikacji badań, których celem byłoby tworzenie doskonalszych stron internetowych, łączących archiwistów i użytkowników ${ }^{18}$. W ostatnich latach można zauważyć wzrost zainteresowania problematyką archiwów i archiwistów w środowisku wirtualnym. W kręgu zainteresowań są takie tematy jak: narzędzia wyszukiwawcze online, rola archiwistów w rozwoju archiwalnego środowiska online, nowe kanały wymiany informacji między archiwistami a użytkownikami ${ }^{19}$.

${ }^{16}$ ARPO Index - Archival Research Preparation Online Index, https://arpoindex.org/ (dostęp 22.06.2020).

17 Patrz: I. G. Anderson, Necessary but Not Sufficient: Modelling Online Archive Development in the UK, „D-Lib Magazine” 1008, t. 14, nr 1/2, http://www.dlib.org/dlib/ january08/anderson/01anderson.html (dostęp 13.09.2020); R. J. Cox, Access in the digital information age and the archival mission: the United States, „Journal of the Society of Archivists" 1998, t. 19, nr 1, s. 25-40; W. Duff, P. Stoyanova, Transforming the Crazy Quilt: Archival Displays from a Users' Point of view, „Archivaria” 1998, t. 45, s. 44-79, https://archivaria.ca/index.php/archivaria/article/view/12224/13243 (dostęp 13.09.2020); W. Landis, Archival Outreach on the World Wide Web, "Archival Issues” 1995, t. 20, nr 2, s. 129-149.

${ }_{18}$ S. P. Pitol, Evaluating How Well an Archival Website Allows a Researcher to Prepare for an On-Site Visit, „American Archivist” 2019, t. 82, nr 1, s. 141.

19 Patrz: C. Bertram, Putting the User First: The Importance of the Reference Archi- 
Scott Pitol dostrzegł w stworzonym przez siebie narzędziu szansę na dokonywanie przeglądu stron archiwów, których celem będzie takie ich przeprojektowywanie by mogły jeszcze lepiej spełniać swą rolę względem użytkowników. Jednak sukces przedsięwzięcia zależny będzie od tego czy archiwiści zdołają zaadoptować kulturę regularnej samooceny i aktualizacji treści stron internetowych $^{20}$. Narzędzie wydaje się ciekawe, dlatego jest warte sprawdzenia, również w warunkach polskich. Wydaje się, że indeks ten może stanowić podstawę do oceny implikowanych w przyszłości zmian.

\section{Analiza zawartości stron internetowych - przyjęta metoda}

Badanie zawartości stron internetowych archiwów, zmierzające do ich porównania pod określonymi względami jest metodą, więc wymaga określenia jego ram. Architektura informacji, funkcjonalność i zawartość serwisów WWW podlega analizom porównawczym od ponad dekady. Pozostaje w kręgu zainteresowań badaczy z zakresu zarządzania oraz bibliotekoznawców ${ }^{21}$. Prowadzenie badań nad internetowymi odsłonami archiwów jest na pewno sposobem dogodniejszym i szybszym niż badania terenowe. Zważyć trzeba również na fakt, że to poprzez sieć internetową użytkownicy coraz częściej pozyskują niezbędne im informacje, a także komunikują się z instytucjami.

Małgorzata Kowalska wyróżniła trzy, najczęściej stosowane metody badań witryn internetowych: techniczną, statystyczną i analityczną, zwaną również ekspercką lub heurystyczną ${ }^{22}$. Przeprowadzone badanie porównawcze, ma na celu przede wszystkim dostrzeżenie najlepszych przykładów działalności archiwów i stworzenie wzorca przygotowywania użytkowników online do wizyty. Analiza porównawcza, coraz częściej nazywana jest w literaturze, z ang. bench-

vist in Online Projects, „Archival Issues” 2019, , t. 40, nr 1, s. 7-23, https://doi.org// archivalissues.11084 (dostęp 13.09.2020); R. Walton, Looking for Answers: A Usability Study of Online Finding Aid Navigation, „The American Archivist” 2017, t. 80, nr 1, s. 30-57, https://americanarchivist.org/doi/pdf/10.17723/0360-9081.80.1.30 (dostęp 13.09.2020); A. Wick, We're All Vegans Here: The Twenty-First Century Archival Ecosystem, „Journal of Archival Organization” 2017, t. 14, nr 1-2, s. 13-34. https://www.tandfonline. com/doi/abs/10.1080/15332748.2018.1503020 (dostęp 13.09.2020).

20 S. P. Pitol, dz. cyt., s. 137, 152.

${ }^{21}$ R. Sapa, Benchmarking $w$ doskonaleniu serwisów WWW bibliotek akademickich, Kraków 2005, s. 37.

${ }^{22}$ M. Kowalska, dz. cyt., s. 118. 
marking i jest zbliżona do trzeciej z wymienionych metod. Niewątpliwie zaletą tej metody jest jej elastyczność - badacz sam określa kryteria, na podstawie których badanie ma zostać przeprowadzone ${ }^{23}$.

Są różne koncepcje benchmarkingu. Ich punktem wspólnym jest przeświadczenie o tym, że odnalezienie odpowiednich wzorców pozwala porównywać działania. Może to być metoda badawcza „służąca identyfikowaniu najlepszych praktyk (liderów), diagnozie i formułowaniu wniosków dla praktyki”24. W znaczeniu szerszym dotyczyć będzie procesu zarządzania zmierzającym do osiągniecia przewagi nad konkurencją ${ }^{25}$. Czyli benchmarking może być postrzegany jako metoda badawcza lub proces doskonalenia ${ }^{26}$.

Remigiusz Sapa przedstawił swoją propozycję realizacji metody benchmarkingu (dla bibliotek uniwersyteckich), która składa się z następujących etapów:

- określenie obszarów i cech, odnoszących się do treści i funkcjonalności serwisów WWW;

- konstruowanie kwestionariusza oceny;

- ocena serwisów WWW za pomocą kwestionariusza;

- porównawcza analiza zebranych danych;

- identyfikowanie najlepszych praktyk i liderów;

- formułowanie wniosków służących bezpośredniemu doskonaleniu serwisów, a w dalszej perspektywie - wskazaniu potencjalnych partnerów dla benchmarkingu procesów ${ }^{27}$.

Przedstawiona propozycja przebiegu badania jest odpowiednia również w kontekście archiwów. Jednak podkreślenia wymaga, że benchmarking w tym przypadku będzie traktowany jako metoda badawcza, której celem będzie doskonalenie jakości świadczonych przez instytucje usług poprzez serwisy WWW. Celem nie będzie zatem ocena poszczególnych elementów, a ich opis. Dlatego etap drugi polegający na konstruowaniu kwestionariusza oceny, w tym przypadku będzie oznaczać uporządkowanie i zgrupowanie wyznaczonych uprzednio obszarów i cech treściowych, w kwestionariusz badawczy służący ich opisaniu. Punktem kończącym badanie będzie wskazanie najmocniejszych punktów postępowania oraz liderów wśród archiwów zagranicznych w postępowaniu z użytkownikiem chcącym przygotować się wirtualnie do wizyty i poszukiwań.

\footnotetext{
23 Tamże.

${ }^{24}$ R. Sapa, dz. cyt., s. 37.

25 Tamże.

26 Tamże, s. 38.

27 Tamże, s. 48.
} 


\section{Dobór próby}

Pierwszym krokiem w podjętym badaniu był wybór stron internetowych zagranicznych archiwów narodowych. Dokonanie analizy wszystkich archiwów krajowych na świecie, które posiadają swoje witryny przekroczyłoby moje możliwości. Pierwszym kryterium zawężającym był wymóg, żeby archiwum posiadało stronę anglojęzyczną lub też jej pełną wersję w tym języku. Wynika to ze znajomości tego właśnie języka. Jak się okazało wiele witryn jest zaopatrzonych w tłumaczenia. Trzeba brać jednak pod uwagę ewentualność, że nie wszelkie treści zostały przetłumaczone z języka ojczystego. Może tak być, jednak zgromadzone $\mathrm{w}$ trakcie badania dane dostarczyły bogatą i różnorodną informację o działaniach archiwów. Skoro nie zmierzałam do oceny działań poszczególnych jednostek, a wskazania dobrych praktyk to uznałam, że jest to argument wystarczająco przemawiający za zasadnością takiego podejścia badawczego. Kolejny krok okazał się najtrudniejszy, tj. ustalenie zbiorowości, z której wybiorę próbę. Postanowiłam oprzeć się na międzynarodowym źródle wiedzy o archiwach. Mój wybór padł na wirtualną odsłonę Międzynarodowej Rady Archiwów ${ }^{28}$. Rada ta dzieli się na oddziały regionalne, z których w badaniu uwzględniłam trzy:

- Oddział Regionalny Pacyfiku PARBICA ${ }^{29}$,

- Północnoamerykańska Sieć Archiwalna NAANICA ${ }^{30}$,

- Europejski Odział Regionalny EURBICA ${ }^{31}$.

Oddziały te są organizacjami profesjonalnymi, w skład których wchodzą archiwa rządowe, pozarządowe, stowarzyszenia archiwalne oraz członkowie reprezentujący wiele narodów ${ }^{32}$. Kontrolowany ich wybór podyktowany były trzema przesłankami: chęcią poznania wzorców amerykańskich i europejskich, obecnością w literaturze zagranicznej badaczy australijskich zajmujących się informacyjnością archiwów i użytkownikami archiwów ${ }^{33}$ oraz większe prawdo-

${ }^{28}$ International Council on Archives, https://www.ica.org/en (dostęp 25.06.2020).

${ }_{29}$ Pacific Regional Branch in International Council on Archives, https://www.ica.org/ en/parbica (dostęp 25.06.2020).

${ }^{30}$ North American Archival Network in International Council on Archives, https:// www.ica.org/en/about-naanica (dostęp 25.06.2020).

31 European Regional Branch in International Council on Archives, https://www.ica. org/en/about-eurbica (dostęp 25.06.2020).

${ }^{32}$ Pacific Regional Branch.

33 Zob. periodyk „Archives and Manuscripts”. 
podobieństwo posiadania przez archiwa w tych regionach stron internetowych w wersji anglojęzycznej.

Na stronie oddziału PARBICA jest lista krajów, które są jego członkami. W oparciu o tę informację oraz listę archiwów narodowych zamieszczoną $\mathrm{w}$ angielskiej wersji bazy wiedzy Wikipedia ${ }^{34}$ rozpoczęłam ostateczne typowanie archiwów do badania. Z regionu Oceanu Spokojnego spośród dwudziestu członków oddziału, wymagania spełniły (posiadanie strony anglojęzycznej) archiwa z Australii, Fidżi, Nowej Zelandii i Vanuatu. Pozostałe gałęzie regionalne nie zamieściły informacji o krajach, które wchodzą w ich skład, w tym przypadku wyboru dokonywałam na podstawie listy osobowej członków oddziałów. Do oddziału NAANICA przynależą przedstawiciele pięciu narodowości, badaniu poddano archiwa: Stanów Zjednoczonych, Kanady, Szwecji, Boliwii. Jeden z przedstawicieli reprezentował Chiny, jednak National Archives Administration of China nie posiada wersji angielskiej witryny WWW. EURBICA zrzesza 900 przedstawicieli różnych europejskich organizacji. Dwa poprzednie oddziały pozwoliły na wytypowanie łącznie 8 serwisów internetowych. Postanowiłam, że względu na dużą liczebność regionu europejskiego instytucje zakwalifikowane do analizy będą stanowić połowę próbę badawczej. Wskazówką była lista członków - wybrałam 8 krajów według kolejności ich występowania na liście. W ten sposób do przyszłego badania wytypowałam archiwa z: Malty, Wielkiej Brytanii, Belgii, Chorwacji, Francji, Holandii, Szwajcarii i Niemiec.

Czy przyjętą próbę można uznać za reprezentatywną? Dobrana zbiorowość, została poddana analizie jakościowej, w której uzyskane dane miały przede wszystkim stanowić jak najpełniejszą i wiarygodną informację o interesującym temacie, a kwestią drugorzędną było to czy reprezentują cechy całej populacji (wszystkich narodowych archiwów na świecie?) ${ }^{35}$. Im pełniejszą zbiorowość poddano by analizie tym pewność wyczerpania tematu byłaby większa, jednak ważniejsze wydało się zaakcentowanie bogactwa stosowanych przez archiwa działań.

${ }^{34}$ List of National Archives, https://en.wikipedia.org/wiki/List_of_national_archives (dostęp 25.06.2020).

35 S. Pasikowski, Czy wielkość jest niezbędna? O rozmiarze próby $w$ badaniach jakościowych, „Przegląd Badań Edukacyjnych” 2015, t. 21, nr 2, s. 203. 


\section{Elementy poddane analizie}

Przeprowadzenie analizy porównawczej poszczególnych stronach internetowych wymagało wyszczególnienia elementów, które będą jej podlegać. Elementy te to konkretne treści służące pośrednio lub bezpośrednio przygotowaniu użytkownika do wizyty osobistej We wcześniej przeprowadzonym przeze mnie badaniu witryn polskich archiwów państwowych skupiłam się na pięciu elementach oceny. Ze wstępnej analizy stron wynikało, że kształcenie użytkowników odbywa się na następujących płaszczyznach ${ }^{36}$ :

1. informacje skierowane do archiwistów zakładowych;

2. informacje skierowane do genealogów;

3. informacje skierowane do użytkowników chcących udać się do archiwum;

4. informacje skierowane do użytkowników chcących odnaleźć materiały archiwalne

5. informacje dotyczące tego jak postępować z dokumentacją/materiałami.

Obecne badanie stanowi kontynuację, jednak jego cel wymagał skupienia się na punktach odnoszących się do użytkowników, których zamiarem będzie udanie się do archiwum. W ten sposób usunęłam punkt pierwszy z poprzedniego badania. Dokonałam powtórnej, wstępnej analizy treści zawartych na stronach, skonfrontowałam je z dostępną literaturą i opracowałam na nowo punkty na podstawie, których oceniałam treści zawarte $\mathrm{w}$ witrynach WWW.

Wnioskiem płynącym z badania poprzedniego była potrzeba stworzenia koszyka z narzędziami szkoleniowymi, który powinien opierać się na trzech zakresach treściowych ${ }^{37}$ :

- wiedzy o archiwum,

- zasadach poszukiwania informacji zawartej w źródłach archiwalnych,

- wykorzystywaniu informacji zawartej w źródłach archiwalnych.

Zakresy te są one ogólne, po to by pozwolić na tworzenie w ich obrębie bardziej szczegółowych zagadnień tematycznych, w zależności od zapotrzebowania. Przeprowadzenie analizy poszczególnych stron internetowych wymagało dalszego uściślenia elementów jej poddanych. Wskazówkę stanowiły dla mnie ustalenia dokonane przez przedstawicieli bibliologii i informatologii, którzy przeprowadzali benchmarking stron internetowych bibliotek. Według Małgorzaty

${ }^{36}$ M. Cołbecka, Oferta archiwów w Internecie, s. 80.

37 Taż, Ustugi informacyjne archiwów. 
Kowalskiej wcześniejszy wybór kryteriów podlegających badaniu jest konieczny. Wyróżniła dwanaście punktów służących ocenie treści i funkcjonalności serwisu WWW. W przypadku badania pod kątem kształcenia użytkowników, interesujące były kryteria treści, wśród których wyróżniła:

1. informacje o bibliotece i jej działalności,

2. zasoby tradycyjne biblioteki w serwisie,

3. katalog online,

4. źródła elektroniczne,

5. usługi,

6. komunikację z użytkownikiem ${ }^{38}$.

Większość punktów wpisuje się w określone przeze mnie zakresy tematyczne przygotowania użytkownika do wizyty w archiwum. Na uwagę w liście stworzonej przez Małgorzatę Kowalską zasługuje punkt ostatni, czyli możliwość kontaktu wirtualnego z pracownikami. W tym przypadku celem byłoby ustalenie czy są to możliwości komunikacji synchronicznej (bezpośrednia relacja) czy asynchronicznej. Przywoływane już narzędzie ARPO Index stworzone przez Scotta P. Pitol'a, również opiera się na ocenie konkretnych komponentów stron internetowych:

1. zadawanie pytań;

2. przeglądanie informacji o zasobie;

3. wyszukiwanie informacji o zasobie;

4. wyświetlanie informacji o wynikach wyszukiwania;

5. gromadzenie wybranych informacji;

6. zapisywanie wybranych informacji;

7. informacje dotyczące planowania wizyty badawczej;

8. zarejestrowanie wizyty badawczej;

9. zamówienie materiałów przed wizytą ${ }^{39}$.

Komponenty te stanowią cenne wskazówki i są szczegółowe (autor w tekście przedstawia elementy, które składają się na poszczególne oceny). Moim celem nie był pomiar określonych elementów, a przeprowadzenie analizy jakościowej i zwrócenie uwagi na najlepsze praktyki. Przytoczone przykłady pozwoliły na opracowanie własnej listy obszarów poddawanych analizie, które przedstawiają się następująco:

1. wiedza o archiwum;

2. przygotowanie do wizyty oraz zasady panujące w czytelni;

${ }^{38}$ M. Kowalska, dz. cyt., s. 120.

39 S. P. Pitol, dz. cyt. 
3. wiedza o zasobie i zasady poszukiwania materiałów archiwalnych;

4. wykorzystywanie informacji zawartej w materiałach archiwalnych szkolenia i materiały edukacyjne;

5. komunikacja z użytkownikiem.

\section{Analiza poszczególnych stron}

Badaniu zostało poddanych szesnaście stron internetowych archiwów narodowych pod względem ustalonych kryteriów, oto lista instytucji ${ }^{40}$ :

- Australia - National Archives of Australia,

- Fidżi - National Archives of Fiji,

- Nowa Zelandia - Archives New Zealand,

- Vanuatu - National Library \& Archives of Vanuatu,

- Kanada - Library and Archives Canada,

- Stany Zjednoczone - The National Archives and Records Administration,

- Szwecja - Riksarkivet,

- Boliwia - The National Archives and Library of Bolivia,

- Malta - National Archives of Malta,

- Wielka Brytania - The National Archives,

- Belgia - State Archives of Belgium,

- Chorwacja - Croatian State Archives,

- Francja - Archives Nationales,

- Holandia - Nationaal Archief,

- Szwajcaria - Swiss Federal Archives,

- Niemcy - Bundesarchiv,

Dla większej przejrzystości dokonanej analizy opisując poszczególne przypadki używam nazwy kraju, a nie instytucji. W trakcie badań właściwych okazało się, że strona internetowa Biblioteki Narodowej i Archiwum Vanuatu ${ }^{41}$ jest nieaktywna, chociaż podczas doboru próby tego problemu nie było. Postanowiłam pozostawić ją w zbiorowości, ponieważ nie otwierająca się witryna jest również ważną informacją w badaniu jej efektywności informacyjnej.

${ }^{40}$ Na końcu artykułu znajduje się wykaz stron internetowych archiwów poddanych analizie.

${ }^{41}$ Stan na 03.07.2020. 
Tabela 1. Występowanie informacji na stronach internetowych archiwów odpowiadających wyszczególnionym kryteriom

KRYTERIA PODDANE ANALIZIE W TRAKCIE BADANIA

\begin{tabular}{|c|c|c|c|c|c|}
\hline & 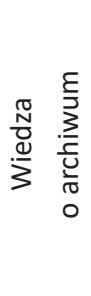 & 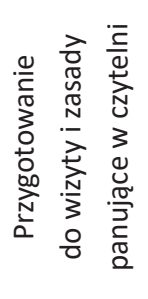 & 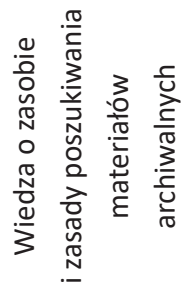 & 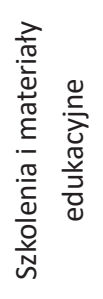 & 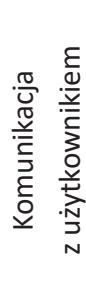 \\
\hline Australia & $x$ & $x$ & $x$ & - & $x$ \\
\hline Fidżi & $x$ & - & $x$ & - & $x$ \\
\hline Nowa Zelandia & $x$ & $x$ & $x$ & $x$ & $x$ \\
\hline \multicolumn{6}{|l|}{ Vanuatu } \\
\hline Kanada & $x$ & $x$ & $x$ & $x$ & $x$ \\
\hline Stany Zjednoczone & $x$ & $x$ & $x$ & $x$ & $x$ \\
\hline Szwecja & $x$ & - & $x$ & - & $x$ \\
\hline Boliwia & $x$ & $x$ & - & - & - \\
\hline Malta & $x$ & $x$ & $x$ & - & $x$ \\
\hline Wielka Brytania & $x$ & $x$ & $x$ & $x$ & $x$ \\
\hline Belgia & $x$ & $x$ & $x$ & $x$ & $x$ \\
\hline Chorwacja & $x$ & $x$ & - & - & $x$ \\
\hline Francja & $x$ & $x$ & $x$ & $x$ & $x$ \\
\hline Holandia & $x$ & $x$ & $x$ & - & $x$ \\
\hline Szwajcaria & $x$ & $x$ & $x$ & - & $x$ \\
\hline Niemcy & $x$ & $x$ & $x$ & $\mathrm{x}$ & $x$ \\
\hline
\end{tabular}

Źródło: opracowanie własne

\section{Wiedza o archiwum}

Archiwa są instytucjami, o których istnieniu społeczeństwo wie, jednak identyfikacja ich misji oraz pełnionych funkcji może już sprawiać trudności. Informacje 
dotyczące instytucji, jej historii, działalności mogą mieć wpływ na budowę zaufania użytkowników ${ }^{42}$. Nie chodzi tu tylko o dane teleadresowe, które są cenne $\mathrm{w}$ momencie potrzeby interakcji z archiwum (wizyty, korespondencji itp.), ale o dane, które pozwolą zrozumieć czym instytucja ta jest. Historia archiwum nie jest stałym elementem uwzględnianym w witrynach WWW (jak mogłoby się wydawać), ponadto zauważyć można tendencję do przedstawiania jej w sposób zwięzły. Jest to informacja występująca na 7 analizowanych stronach internetowych (Fidżi, Malta, Belgia, Francja, Szwajcaria, Szwecja, Boliwia).

Archiwa przedstawiając się w środowisku WWW częściej dążą do opisania wizji oraz misji swojego istnienia, które określane są w niektórych przypadkach mianem roli lub zadań. Tego rodzaju informacje zostały zamieszczone aż w 13 przypadkach (Fidżi, Nowa Zelandia, Malta, Wielka Brytania, Belgia, Chorwacja, Francja, Holandia, Szwajcaria, Niemcy, Kanada, USA, Szwecja). Opis często nawiązuje do roli jaką archiwa mogą spełnić w społeczeństwie informacyjnym:

It is essential that archives provide to the public an immediate and reliable insight into the past to encourage research and to contribute to realization of basic values of democratic society - public rights, transparency and accountability ${ }^{43}$.

Jest to cytat zaczerpnięty ze strony chorwackiej. Informacje o misji archiwów najczęściej znajdują się w zakładce „About us”, jednak zdarzają się przypadki, że użytkownik już na stronie głównej zostanie poinformowany o roli jaką te instytucje pełnią, jak np. w serwisie Archiwum Narodowego Malty:

In today's information society, the internet plays a vital communications role. The National Archives is a crucial player in this rapidity-changing information society. We have a very important mission to fulfill. The National Archives Act (V-2005) challenges us with the responsibility to "preserve the collective memory of the Maltese nation..." This is not an easy task to fulfill ${ }^{44}$.

Użytkownicy mogą wirtualnie zapoznać się z aktami prawnymi normującymi prace archiwów, ich strukturą organizacyjną, przyjętymi strategiami. Dla

${ }^{42}$ M. Kowalska, dz. cyt., s. 121.

${ }^{43}$ Search the Records. Croatian State Archives, http://www.arhiv.hr/en-gb/Searchthe-records (dostęp 04.07.2020).

${ }^{44}$ Introduction by the National Archivist. National Archives of Malta https://nationalarchives.gov.mt/en/Pages/default.aspx (dostęp 04.07.2020). 
osoby początkujące jeszcze ciekawsze wydają się wyjaśnienia dotyczące instytucji archiwalnej, które pomagaj zrozumieć czym ona jest. Archiwum w Malcie i Wielkiej Brytanii zamieściło na stronie informacje o tym co różni archiwa od bibliotek, ponadto na stronie pierwszej z wymienionych instytucji dowiemy się czym zajmuje się archiwista. Użytkownik w pięciu przypadkach, odnajdzie odpowiedzi na pytania dotyczące m.in.:

- czym jest archiwum (Fidżi, Wielka Brytania, Belgia, Chorwacja, Holandia, Stany Zjednoczone), w archiwum szwajcarskiego jest to broszura w języku niemieckim, która tłumaczy czym są archiwa federalne i co można w nich odnaleźć;

- czym jest zarządzanie dokumentacją (Fidżi);

- po co przechowywać materiały archiwalne (Fidżi).

Na szczególną uwagę zasługują serwisy archiwum Niemiec i USA, które już od wejścia użytkownika na stronę główną starają się kompleksowo go przeprowadzić przez ścieżkę zapoznania się z instytucja, jak i poszukiwania źródeł. Na stronie powitalnej Bundesarchiv znajduje się wprowadzenie do korzystania ze strony, w zwartym tekście osoba odnajdzie przekierowania do miejsc, gdzie może odnaleźć odpowiedzi na nurtujące go pytania, np.

- jeśli zastanawiasz się nad wizytą badawczą w jednej z naszych czytelni, chciałbyś zamówić kopie materiałów archiwalnych lub zadać konkretne pytanie, znajdziesz przydatne wskazówki w sekcji „Korzystanie ”,

- wybierając jeden z następujących tematów, zostaniesz poprowadzony bezpośrednio do bardziej szczegółowych informacji: Planuję wizytę na miejscu w Archiwum Federalnym; Szukam zdjęć; Chciałbym znaleźć informacje na temat przodka.

W ten sposób objaśniona została w pełni architektura strony archiwum. Użytkownik, o ile oczywiście przeczyta te powitalne wskazówki, nie będzie miał problemu z odnalezieniem interesujących go zakładek. Wydaje się to ważne, dla przykładu archiwum australijskie, chociaż posiada stronę nastawioną na obsługę użytkownika (głównie w zakresie informowania o zasobie, niż o instytucji) i jest wizualnie bardzo atrakcyjna, to jednak ma bardzo zawiłą architekturę, z wielokrotnymi powtórzeniami informacji, co powoduje, że można się na niej „zgubić”. Archiwum niemieckie jako jedyne zamieściło słownik archiwalny, jednak tylko w języku niemieckim.

Strona archiwum amerykańskiego w bardzo podobny sposób podeszła do obsługi użytkownika początkującego. W zakładce, w której informuje o samej instytucji odnajdziemy dział pt. „Nowy w archiwum?”. W tym miejscu osoba poza dowiedzeniem się czym jest archiwum, kim jest archiwista oraz co to 
są materiały archiwalne odnajdzie „FAQ” - odpowiedzi na często zadawane pytania. Jest to dział bardzo szeroko potraktowany, w którym rozwiewane są wątpliwości dotyczące m.in.: korzystania ze strony internetowej, ponoszonych kosztów, dokumentów jakie są dostępne online, jak rozpoczynać badania, na jakie pytania szukać odpowiedzi w bibliotekach, czy sposobu cytowania itd.

\section{Przygotowanie do wizyty oraz zasady panujące w czytelni}

Informacje, które powinny przygotować użytkownika do bezpośredniej wizyty na miejscu są clue omawianego zagadnienia. Co to archiwum, lub jak wygląda poszukiwanie źródeł stanowią wiedzę dodatkową, ich poznanie zależy od dociekliwości badacza. Z dokonanej analizy stron internetowych wynika, że instytucje archiwalne kładą duży nacisk na zamieszczanie informacji wskazujących użytkownikom jakie kroki przedsięwziąć przed i w trakcie wizyty osobistej. Jedynie dwa archiwa (Fidżi i Szwecja) nie zamieściły w swoich witrynach omawianych informacji.

Powszechnie archiwa zamieszczają dane teleadresowe, godzin otwarcia, regulaminy czytelni. Można zauważyć, że instytucie te pomimo formalnego charakteru tego rodzaju informacji starają się je dostosować do jak najszerszej i różnorodnej grupy odbiorców. Co to oznacza? Czasem odnajdujemy adres nie tylko danej placówki, ale wszystkich archiwów w kraju (Francja) i wskazówki dojazdu (Wielka Brytania, Holandia, Stany Zjednoczone). Godziny otwarcia podawane są z informacją na temat dni w roku, gdy archiwum jest zamknięte, a regulaminy czytelni wraz z mapą ich rozmieszczenia w całym państwie (Malta). Dwa archiwa umieściły na stronie informację dedykowaną osobom niepełnosprawnym (Wielka Brytania, Francja). Czasem dowiemy się, że instytucje archiwalne to nie tylko miejsca, gdzie poszukuje się źródeł, niektóre z nich gwarantują swoim użytkownikom i inne atrakcje, takie jak wystawy, punkty gastronomiczne, czy sklepy (np. Wielka Brytania).

Strony internetowe archiwów pozwalają użytkownikom coraz efektywniej przygotować się do wizyty. Aż dziewięć poddanych badaniu witryn zgromadziło kompleksową informację dotyczącą planowania odwiedzin archiwum. Zauważyłam tendencję do trzech rodzajów podejść w grupowaniu informacji:

- podział informacji ze względu na etapy poszukiwań informacji, tj. przed wizytą i w jej trakcie;

- $\quad$ rzeczowy podział informacji, w tym odpowiedzi na różne pytania w postaci FAQ; (Nowa Zelandia, np. czy korzystanie jest płatne, zamawianie 
kopii, czy każdy ma dostęp do akt, czy można robić zdjęcia, czy dzieci mogą odwiedzić czytelnię);

- podział informacji według typu użytkownika.

Najczęściej pojawia się typ pierwszy. Archiwum nowozelandzkie podało kroki, jakie trzeba podjąć przed samą wizytą oraz prawa i obowiązki użytkownika, których powinien przestrzegać w trakcie wizyty. Co interesujące, kolejne etapy mają na stronie swoje wytłumaczenie, np. archiwista będzie mógł efektywniej pomóc poszukiwaczowi, gdy ten przyjdzie do archiwum ze zgromadzoną jak największą ilością informacji do badanego tematu. Podobną praktykę stosują też inne archiwa. Archiwum w Wielkiej Brytanii przygotowuje użytkowników do badań etapami - w domu i w archiwum. Co do wizyty w instytucji przestrzega, żeby przynieść ze sobą dużo cierpliwości i wytrwałości, ponieważ badania trwają, a materiały archiwalne mogą znajdować się w różnych miejscach, ponadto w archiwum można nie odnaleźć tego czego się poszukuje, ale natrafić na nowe źródła o istnieniu, których nie miało się pojęcia. Ten punkt rozwinęli Chorwaci, którzy przygotowując użytkowników do wizyty wytłumaczyli zasady rozmieszczenia i układu zasobu archiwalnego. Użytkownicy mogą dowiedzieć się też, że archiwalia są niepowtarzalne, dlatego, żeby mogły służyć obecnym i przyszłym badaczom trzeba traktować je ze szczególną troską (Holandia).

Kompleksowe przygotowywanie użytkowników do wizyty poprzez stronę internetową, nie zwalnia archiwistów od pomocy bezpośredniej w trakcie kwerendy, o czym również informują (Holandia, Niemcy, Kanada). Archiwum holenderskie wskazuje, że o pomoc w badaniach można prosić pracownika w punkcie informacyjnym, a jeśli pojawi się trudność w pracy z samymi aktami to archiwistów dyżurujących w czytelni. Duży nacisk na pomoc bezpośrednią kładą również Kanadyjczycy. Na stronie archiwum dowiadujemy się, że ich pracownicy dostępni są, żeby pomagać: w badaniach, odnalezieniu odpowiedzi na zapytania, korzystaniu z zasobu. Niemcy ponadto sugerują wcześniejszy kontakt z instytucją, żeby pracownicy do wizyty użytkownika mogli się lepiej przygotować.

Rzeczowy podział informacji występuje na stronach archiwów w Australii i Wielkiej Brytanii, chociaż w obu przypadkach mamy też do czynienia $\mathrm{z}$ etapowym sposobem jej przedstawienia. Archiwum australijskie informuje użytkownika w jednym miejscu o lokalizacji, godzinach otwarcia, ośrodkach badawczych (tutaj wskazówki m.in. o tym co przygotować przed wizytą, przeglądaniu materiałów archiwalnych, jak wyglądają bazy danych, dostęp do WiFi, zleceniu dokonania kwerendy), innych oferowanych usługach i sklepie. Wielka Brytania na swojej stronie zamieściła informacje w formie odpowiedzi na pytania dotyczące prowadzenia badań, tj. wskazówki dla korzystających po 
raz pierwszy, jak zamawiać, korzystać z dokumentów i je kopiować, co można zabrać do czytelni, jakie akta są zgromadzone, czego można spodziewać się podczas badań, czy potrzebna jest karta użytkownika, korzystanie z biblioteki i korzystanie z akt, map, planów, książek (szczegółowe wskazówki postępowania z aktami opatrzone fotografiami).

Archiwiści belgijski stworzyli wyróżniające się na tle pozostałych instytucji menu na stronie głównej, grupujące informacje dla konkretnych typów użytkowników. Są tu zakładki dedykowane: naukowcom, genealogom, urzędnikom, dziennikarzom, nauczycielom oraz notariuszom. Odnajdą oni w ten sposób informacje dotyczące przygotowania się do poszukiwań, publikacje, wyszukiwarki, ale też odpowiedzi na najczęściej pojawiające się pytania i wątpliwości. Mieszany typ przekazywania informacji na swojej witrynie WWW prezentuje Archiwum Narodowe Stanów Zjednoczonych. Użytkownik odnajdzie tu informację uszeregowaną etapami, ale też skierowaną do danego typu badaczy (genealogów i weteranów wojennych), czy dotyczącą tematyki badawczej. Wskazówki dla genealogów pojawiają się też na stronach archiwum Chorwacji i Kanady.

Na poszczególnych stronach archiwów krajowych można odnaleźć inne ciekawe inicjatywy przygotowujące do wizyty. Chorwacja oraz Francja oferują użytkownikom wycieczki z przewodnikiem po archiwum. Na stronach Niemiec i Kandy odnajdziemy listę firm lub badaczy, którzy mogą wykonać kwerendę na zlecenie. Wielka Brytania odpowiada na pytania nieszablonowe: co zrobić z dużym bagażem podczas wizyty, co zabrać do czytelni, czy można przyprowadzić zwierzęta, czy na terenie archiwum można palić.

Ważny składnikiem będą też możliwe do pobrania ze strony dokumenty lub usługi online, jak formularze zamówienia czy karty czytelnicze. Archiwa zamieszczają również materiały szkolące, jak np. video pt. „How to Begin your Search Online” (Kanada) czy prezentację pt. „Help Us Protect the Records” (Stany Zjednoczone), z którą zapoznanie się jest obligatoryjne.

\section{Wiedza o zasobie i zasady poszukiwania materiałów archiwalnych}

Kolejną kwestią, która wymaga poznania jest zasób archiwum, czyli co jest w archiwum przechowywane oraz w jaki sposób z materiałów tych korzystać. Analiza wszystkich stron internetowych pozwala wysnuć wniosek, że chociaż instytucje te w większości omawiają swój zasób, robią to skrótowo. Poruszają przy tym dwie kwestie - wskazują jakich materiałów nie gromadzą (Wielka 
Brytania) oraz co dostępne jest online (Szwecja, Nowa Zelandia). Temat ten ujmowany jest w przystępnej formie, celem nie jest tu stworzenie wizytówki archiwum, a bycie istotną pomocą szkoleniową dla użytkownika. Dla przykładu archiwum szwajcarskie opisuje instytucję jak miejsce, które gromadzi szczegółowe informacje historyczne, omawiając zasób wskazuje na często poszukiwane tematy i udziela wskazówek dla dalszych badań, tłumaczy również czym są materiały tradycyjne i elektroniczne.

Powszechną praktyką jest zamieszczanie na stronach internetowych baz danych jako pomocy $\mathrm{w}$ wyszukiwaniu źródeł w zasobie. Niekiedy są to pojedyncze wyszukiwarki, czasem archiwa dysponują kilkoma tematycznymi lub rzeczowymi (np. Kanada) lub są to rozbudowane portale z możliwością logowania, zamawiania jednostek archiwalnych, kopii cyfrowych, zapisywania wyników wyszukiwania czy możliwością wnioskowania o konsultację ze specjalistą (Francja, Szwajcaria). Niestety mniej archiwów zapewnia instrukcję obsługi do proponowanych baz danych (Francja, Holandia, Nowa Zelandia, Malta).

Archiwa świadczą pomoc nie tylko w poszukiwaniach online. Nowa Zelandia oferuje użytkownikom kompleksową informację również o kwerendzie tradycyjnej w zakładce „Jak przeprowadzić badania”, w tym wskazówki dotyczące: pierwszych kroków, śledzenia swoich badań, maksymalnego wykorzystania czasu w czytelni. Niemcy bezpośrednio ze strony głównej wskazują, gdzie użytkownik odnajdzie interesujące go zakresy tematyczne: przekierowanie do odpowiednich baz danych, dostępnego zasobu cyfrowego, poszukiwanie fotografii czy informacji o przodkach.

Coraz więcej aspektów związanych z poszukiwaniem i korzystaniem z materiałów archiwalnych przenosi się do środowiska wirtualnego. Niektóre archiwa umożliwiają użytkownikom zamawianie akt poprzez serwisy WWW i dostęp do nich online (o ile zostały zdigitalizowane).

Konsultacje z archiwistą w przypadku problemów w wyszukiwaniu źródeł gwarantują archiwa w Kanadzie, Niemczech, Fidżi i Szwajcarii i Wielkiej Brytanii. Archiwum francuskie proponuje odbycie szkolenia w tym zakresie, podczas którego użytkownik pozna archiwa oraz najbardziej aktualne narzędzia dostępu.

\section{Wykorzystywanie informacji zawartej w materiałach archiwalnych - szkolenia i materiały edukacyjne}

Otwartość archiwów i dostępność do materiałów archiwalnych nie są równoznaczne z umożliwieniem odnalezienia i odczytania informacji w nich zawartych. 
Źródła historyczne chociaż fizycznie odnalezione, mogą zostać nieodczytane lub niezrozumiane przez użytkownika. Przeszkodą może być język, pismo, terminologia czy trudność ze zrozumieniem istotnego, kontekstowego znaczenia informacji. Jednak tylko siedem badanych stron zawiera informacje, które mogłam zakwalifikować do tego działu i niestety były to zazwyczaj komunikaty szczątkowe.

Wskazówki dotyczące badań materiałów dotyczących określonych tematów zamieściła Nowa Zelandia oraz Stany Zjednoczone, jednak szczególny nacisk położono na poszukiwanie tych materiałów, a nie ich wykorzystanie. Archiwum belgijskie udostępniło przewodnik po badaniach archiwalnych - krok po kroku. Ze względu na to, że jest on jedynie w języku holenderskim i francuskim trudno wnioskować czy uczy użytkowników korzystania z materiałów archiwalnych.

Najciekawszą inicjatywą wykazało się Brytyjskie Archiwum Narodowe, które zamieściło na swojej stronie WWW dwa samouczki. Pierwszy dotyczy tworzenia własnego archiwum przez niearchiwistów, a drugi pt. „Reading old documents” odczytywania źródeł historycznych. Jest to jedyna taka propozycja ucząca online. Archiwum francuskie poprzez witrynę internetową informuje o działaniach podobnych, jednak wymagających kontaktu bezpośredniego. Są to płatne lekcje paleografii i warsztaty indywidualne lub rodzinne, dotyczące również wiedzy o archiwum (przykładowy temat: co to jest materiał archiwalny).

Archiwa uczą też swoich użytkowników dalszych czynności związanych $\mathrm{z}$ wykorzystaniem informacji: dostępu do danych osobowych, reguł ograniczenia dostępu, kwestii związanych z prawami autorskimi czy cytowaniem źródeł.

\section{Komunikacja z użytkownikiem}

Strony internetowe przestały już być statycznym przekaźnikiem informacji, a stały się jednym z możliwych kanałów komunikacji z użytkownikiem, jednak i tu są wyjątki. Archiwum boliwijskie nie zawarło żadnych danych, a trzy inne (Fidżi, Chorwacja, Szwecja) umieściły jedynie te podstawowe, jak adres, e-mail czy numer telefonu.

Częstą możliwością kontaktu jest umieszczanie na stronie gotowego formularza kontaktowego, gdzie użytkownik wprowadza określone dane. Może to być formularz ogólny, służący załatwieniu wszystkich spraw lub szczegółowy jak w archiwum Kanady (dla genealogów) i Australii (dla różnych rodzajów pytań, ponadto można śledzić postęp realizacji zlecenia). Archiwum francuskie posiada formularz ogólny, dodatkowo użytkownik, który jest zalogowany w katalogu, 
może w ten sposób poprosić o konsultację. Archiwum amerykańskie przed skorzystaniem z możliwości zapytania odsyła do strony zewnętrznej „History Hub”, jest to centrum historii, gdzie (jak jest sugerowane) znajdują się odpowiedzi na wiele wątpliwości badawczych.

Najbardziej bezpośrednim kanałem kontaktu wirtualnego jest czat online, na który zdecydowały się archiwum brytyjskie i szwajcarskie, z tym, że drugie $\mathrm{z}$ nich zastrzegło $\mathrm{w}$ jakich dniach i godzinach poradnictwo się odbywa. Wydaje się to słuszne, ponieważ nie można wymagać od tego rodzaju instytucji, że pracownicy będą dyżurować prze całą dobę. Dzięki takiej informacji użytkownik wie, kiedy będzie mógł się skonsultować w czasie rzeczywistym.

Na szczególną uwagę zasługują działania podjęte przez dwie instytucje. Archiwum brytyjskie oprócz umieszczenia podstawowych danych teleadresowych, formularza zapytania, umożliwienia użytkownikom rozmowy online ze swoimi pracownikami, wskazuje na inne możliwości odnalezienia odpowiedzi na nurtujące pytania. Archiwum zwraca uwagę, żeby przed przesłaniem zapytania zapoznać się z opublikowanymi przewodnikami badawczymi i wskazuje jakich materiałów archiwalnych nie posiada, zarazem podając namiary na odpowiednie instytucje. Kanadyjczycy oferują użytkownikom spotkania online ze specjalistą po uprzednim umówieniu się poprzez formularz. Osoba ta może wskazać jaki termin preferuje oraz kanał komunikacji (na miejscu, poprzez Skype czy na miejscu), jednocześnie proszona jest o szczegółowe opisanie swojego problemu oraz uprzednie skorzystanie z sugerowanych na stronie źródeł informacji.

\section{Wnioski}

Każdy z badanych serwisów WWW nosi cechy sugerujące co dla archiwistów w danym kraju, w kontaktach wirtualnych z użytkownikiem jest szczególnie ważne. Podam przykłady. Australijska strona internetowa jest nastawiona na użytkownika, jednak znajduje się na niej wiele powtórzeń informacji, co sprawia, że architektura informacji jest zawiła. Skupia nie na informowaniu o instytucji, a o zasobie i jak z niego korzystać (podobnie jak Nowa Zelandia). Fidżi i Malta przy dużo mniejszym rozbudowaniu formalnym serwisów oferują przede wszystkim informacje o archiwum. Wielka Brytania proponuje pomoc zróżnicowaną - dla początkujących i bardziej zaawansowanych użytkowników, a Belgia dla określonego typu poszukiwaczy (genealodzy, nauczyciele itd.). Niektóre strony wydają się bardziej czytelne (Francja lub Niemcy), inne mniej (Holandia). Archiwum szwajcarskie kładzie nacisk na wsparcie użytkowników 
poszukujących źródeł online, dlatego pomagają mu zrozumieć czym jest archiwum i co przechowuje. Strona kanadyjska czy amerykańska nastawione są na pomoc w prowadzeniu samodzielnych badań i przygotowanie do pierwszej wizyty. Szwecja stara się zapoznać otoczenie z zasobem zdigitalizowanym i dostępnymi wyszukiwarkami. Boliwia dysponuje wciąż stroną, która bardziej jest wizytówką niż kanałem komunikacji z użytkownikiem.

Przeprowadzona analiza przyniosła dwa wnioski. Po pierwsze archiwa stosują różnorodne podejścia w zaznajamianiu użytkowników z funkcjonowaniem archiwów oraz poszukiwaniami, co nie może dziwić. Po drugie, poszczególne rozwiązania można z łatwością adaptować do warunków rodzimych. Z pewnością niektóre sposoby są warte szczególnej uwagi jako pomocne narzędzia w szkoleniu osób chcących odwiedzić polskie archiwa.

Przeanalizowane strony internetowe przestają stanowić jedynie źródło formalnej informacji o archiwach. Przechodzimy do modelu funkcjonalnego (instytucja poprzez stronę realizuje swoje zadania) i bardziej interaktywnego (jest to sposób komunikacji z użytkownikiem). Ostatnimi etapami badania za pomocą metody benchmarkingu jest identyfikowanie najlepszych praktyk i formułowanie wniosków zmierzających do doskonalenia serwisów WWW. Poznanie wybranych, zagranicznych serwisów internetowych pozwoliło na wskazanie tendencji i praktyk, które dla archiwów chcących jak najefektywniej przygotowywać swoich użytkowników do prowadzenia poszukiwań archiwalnych powinny stanowić inspirację, oto one:

- strony internetowe archiwów powinny charakteryzować się prostą architekturą informacji, a hasła, które mogą być niezrozumiałe poza środowiskiem archiwistów mogłyby być w miejscu swego występowania tłumaczone (do słownika nie każdy dotrze);

- $\quad$ archiwa nie skupiają się na zapoznawaniu użytkownika $\mathrm{z}$ historią instytucji, a z misją i zadaniami, które realizują, co ma na celu uzasadnienie ich istnienia oraz roli jaką spełniają w społeczeństwie;

- poznanie zasobu powinno wskazywać na materiały posiadane oraz inne, mogące budzić zainteresowanie jednak znajdujące się gdzie indziej;

- informacje przygotowujące do wizyty w archiwum pogrupowane etapowo, np. przed wizytą i podczas wizyty;

- udostępnienie poradnika dla początkujących użytkowników;

- zasady poszukiwania materiałów archiwalnych przygotowane dla określonych typów użytkowników (naukowcy, genealodzy itd.);

- rozbudowany kanał komunikacji w użytkownikiem, w tym wspieranie go w poszukiwaniach, w postaci czatów online (na zasadzie dyżurów) 
lub możliwości umówienia się na konsultację ze specjalistą (online lub na miejscu).

\section{Wykaz stron internetowych archiwów poddanych analizie (Stan na 15 lipca 2020 r.)}

Australia, National Archives of Australia, https://www.naa.gov.au/

Belgia, State Archives of Belgium, http://www.arch.be/index.php?l=en

Boliwia, The National Archives and Library of Bolivia, http://www.nationallibraryofbolivia.org/

Chorwacja, Croatian State Archives, http://www.arhiv.hr/en-gb

Fidżi, National Archives of Fiji, http://www.archives.gov.fj/

Francja, Archives Nationales, http://www.archives-nationales.culture.gouv.fr/

Holandia, Nationaal Archief, https://www.nationaalarchief.nl/

Kanada, Library and Archives Canada, https://www.bac-lac.gc.ca/eng/Pages/home.aspx

Malta, National Archives of Malta, https://nationalarchives.gov.mt/en/Pages/default.aspx

Niemcy, Bundesarchiv, https://www.bundesarchiv.de/DE/Navigation/Home/home.html

Nowa Zelandia, Archives New Zealand, https://archives.govt.nz/

Stany Zjednoczone, The National Archives and Records Administration, https://www. archives.gov/

Szwajcaria, Swiss Federal Archives, https://www.bar.admin.ch/bar/de/home.html

Szwecja, Riksarkivet, https://riksarkivet.se/

Wielka Brytania, The National Archives, https://nationalarchives.gov.uk/

Vanuatu, National Library \& Archives of Vanuatu, https://www.vanla.org/services

\section{Bibliografia}

Anderson, Ian G. „Necessary but Not Sufficient: Modelling Online Archive Development in the UK". D-Lib Magazine 14, nr 1/2 (2008). https://doi.org/10.1045/january2008anderson.

ARPO Index. „ARPO Index - Archival Research Preparation Online Index”. Dostęp 22.06.2020. https://arpoindex.org/.

Barczak, Henryk. Wybrane zagadnienia informacji archiwalnej. Warszawa: CINTE, 1975.

Barczak, Henryk, Stanisław Nawrocki, i Czesława Włodarska. „Zagadnienia informacji naukowej w archiwach państwowych". Archeion 56 (1971): 33-49.

Bertram, Cara S. „Putting the User First: The Importance of the Reference Archivist in Online Projects." Archival Issues 40, nr 1 (2019): 7-23. 
Bielińska, Maria. „Stan i zadania archiwów wobec aktualnych potrzeb nauki historycznej". Archeion 26 (1956): 3-17.

Chorążyczewski, Waldemar. „Archiwista przyszłości - edukator i autopromotor w społeczeństwie informacyjnym". W Archiwa $w$ nowoczesnym społeczeństwie: pamiętnik V Powszechnego Zjazdu Archiwistów Polskich, Olsztyn 6-8 września 2007 r., zredagowali Jarosław Porazinski i Krzysztof Stryjkowski, 45-53. Warszawa: Stowarzyszenie Archiwistów Polskich, 2008.

Cołbecka, Monika. „Oferta archiwów w Internecie w zakresie kształcenia użytkowników”. W Popularyzacja nauk historycznych - teoria i praktyka. Zbiór studiów, zredagowali Dominika Gołaszewska-Rusinowska, Małgorzata Mielewska, i Tomasz Sińczak, 65-80. Toruń: Instytut Promocji Historii, 2018.

Cołbecka, Monika. „Usługi informacyjne archiwów”. Uniwersytet Mikołaja Kopernika, 2020.

Cox, Richard J. „Access in the Digital Information Age and the Archival Mission: The United States". Journal of the Society of Archivists 19, nr 1 (1998): 25-40. https:// doi.org/10.1080/00379819809514420.

Degen, Robert. „Witryna internetowa archiwum - wizytówka czy element systemu informacji naukowej". W Historyk - archiwista - komputer: historyk a nowoczesny system informacji archiwalnej: materiały z konferencji Toruń, 10 i 11 kwietnia 2003 roku, zredagowali Robert Degen i Halina Robótka, 129-39. Toruń: Wydawn. Uniwersytetu Mikołaja Kopernika, 2004.

Duff, Wendy, i Penka Stoyanova. „Transforming the Crazy Quilt: Archival Displays from a User's Point of View". Archivaria 45 (1998): 44-79.

Główny Urząd Statystyczny. „Społeczeństwo informacyjne w Polsce w 2019 roku”. Dostęp 21.06.2020. https://stat.gov.pl/obszary-tematyczne/nauka-i-technika-spoleczenstwo -informacyjne/spoleczenstwo-informacyjne/spoleczenstwo-informacyjne-w-polsce-w2019-roku,2,9.html.

Gołembiowski, Maciej. „Potrzeby informacyjne użytkowników informacji archiwalnej”. Zagadnienia Infromacji Naukowej, nr 1 (1979): 85-110.

Gołembiowski, Maciej. System informacji archiwalnej. Warszawa; Łódź: Państwowe Wydawn. Nauk, 1985.

Gmiterek, Grzegorz. „Od Web 1.0 do Web 3.0. Interaktywność a ewolucja sieci”. W Nauka o informacji, zredagował Wiesław Babik, 599-620. Nauka, Dydaktyka, Praktyka 174. Warszawa: Stowarzyszenie Bibliotekarzy Polskich, 2016.

Hejnosz, Wojciech. „Jeszcze o archiwach, bibliotekach i ich publicznej użyteczności naukowej". Archeion 16 (1939 1938): 85-94.

Igielski, Andrzej. „Potrzeby informacyjne indywidualnych użytkowników dokumentacji archiwalnej”. Archiwista 15, nr 1-2 (1979): 25-34.

ICA. „International Council on Archives”. Dostęp 25.06. 2020. https://www.ica.org/en.

Landis, William. „Archival Outreach on the World Wide Web”. Archival Issues 20, nr 2 (1995): 129-49.

„List of National Archives”. W Wikipedia, 25.06.2020. https://en.wikipedia.org/w/index. php?title=List_of_national_archives\&oldid=994125169. 
Kowalska, Małgorzata. „Analiza porównawcza jakości serwisów WWW bibliotek wyższych szkół niepaństwowych województwa kujawsko-pomorskiego”. Folia Toruniensia 8 (2008): 117-35.

Kroll, Bogdan. „Charakter i perspektywy tradycyjnego i archiwalnego systemu wyszukiwania informacji”. Archeion 65 (1977): 61-84.

Magier, Dariusz. „Archiwa, studenci i Internet, czyli archiwistyka i archiwa widziane przez monitor PC. Raport z badań”. Archiwista Polski 19, nr 4 (2014): 71-79.

Nawrocki, Stanisław. „Archiwum jako ośrodek informacji”. Infromatyka i Archiwa 11 (1981): 3-18.

Nawrocki, Stanisław. Komputer w stużbie archiwalnej. Poznań: Naczelna Dyrekcja Archiwów Państwowych w Warszawie, 1985.

Nawrocki, Stanisław. „Kształcenie użytkowników informacji w archiwach”. Archeion 72 (1981): 7-15.

Pasikowski, Sławomir. „Czy wielkość jest niezbędna? O rozmiarze próby w badaniach jakościowych”. Przegląd Badań Edukacyjnych 2, nr 21 (2016): 195-211. https://doi. org/10.12775/PBE.2015.055.

Pitol, Scott P. „Evaluating How Well an Archival Website Allows a Researcher to Prepare for an On-Site Visit". The American Archivist 82, nr 1 (2019): 137-54. https://doi. org/10.17723/0360-9081-82.1.137.

„Rozporządzeniem Ministra Nauki i Szkolnictwa Wyższego z dnia 20 września 2018 r. w sprawie dziedzin nauki i dyscyplin naukowych oraz dyscyplin artystycznych." Dziennik Ustaw Rzeczypospolitej Polskiej, poz. 1818 (2018).

Ryszewski, Bohdan. Problemy i metody badawcze archiwistyki. Toruń: Wydaw. UMK, 1985.

Sapa, Remigiusz. Benchmarking $w$ doskonaleniu serwisów WWW bibliotek akademickich. Zeszyty naukowe Uniwersytetu Jagiellońskiego 1276. Kraków: Wydawnictwo Uniwersytetu Jagiellońskiego, 2005.

Walton, Rachel. „Looking for Answers: A Usability Study of Online Finding Aid Navigation". The American Archivist 80, nr 1 (2017): 30-52. https://doi.org/10.17723/03609081.80.1.30.

Weber, Hartmut. „Skorzystaj z klucza i zagraj w grę - archiwa w społeczeństwie informacyjnym i kształcącym się". Archeion 107 (2004): 15-26.

Wick, Amanda. „We're All Vegans Here: The Twenty-First Century Archival Ecosystem”. Journal of Archival Organization 14, nr 1-2 (2017): 13-34. https://doi.org/10.108 0/15332748.2018.1503020.

Słownik języka polskiego PWN. „wizytówka”. Dostęp 25.06.2020. https://sjp.pwn.pl/ sjp/wizytowka;2579957.html.

Wójcikowa, Stefania, i Jan Rogala. „Udostępnianie zbiorów w pracowni Archiwum Państwowego m.st. Warszawy w latach 1967-1977”. Archeion 69 (1979): 207-20.

„Zależności między nową klasyfikacją dziedzin i dyscyplin a wcześniej obowiązującym wykazem i systematyką OECD”. Dostęp 11.09.2020. https://konstytucjadlanauki. gov.pl/content/uploads/2018/09/nowy-podzia-dyscyplin-tabela.pdf. 
